\title{
FDI DETERMINANTS IN LEAST RECIPIENT REGIONS: THE CASE OF SUB-SAHARAN AFRICA AND MENA
}

Godwin Okafor* Jenifer Piesse** Allan Webster***

* godwin.okafor@solent.ac.uk

School of Business, Law and Communications, Southampton Solent University, UK

**jpiesse@bournemouth.ac.uk

Business School, Bournemouth University, UK

Stellenbosch University, South Africa

*** awebster@bournemouth.ac.uk

Business School, Bournemouth University, UK

\begin{abstract}
This paper explores the determinants of FDI into FDI least recipient regions. Panel data for 20 Sub-Saharan Africa (SSA) and 11 Middle East and North Africa (MENA) countries are used for the period 2000 - 2012. Findings of the fixed effects estimations suggest that FDI inflows into these regions are influenced by GDP per capita, infrastructure development, trade openness, and control of corruption. Conversely, inflation negatively affects FDI inflows and rents from natural resources do not significantly influence FDI. Furthermore, the findings show that marginal benefits from any increase in the quantity of FDI determinants (with the exception of control of corruption) will be less for SSA countries. The paper concludes with important policy implications deduced from the findings.
\end{abstract}

Key words: FDI, Least Recipient Regions, Sub-Saharan Africa, MENA

\section{Introduction}

Sub-Saharan Africa (SSA) and the Middle East and North Africa (MENA) receive the lowest levels of FDI inflows in the world with the SSA and the MENA regions receiving around 2\% and 5\% respectively of all global FDI inflows (WDI, 2015). The poor record of FDI flows into these regions is surprising considering the quality and quantity of natural 
resources and their strategic location. It is often argued that the high levels of instability and corruption, weak governance, and poor quality infrastructure account for their inability to attract FDI (Kandiero and Chitiga, 2006). However, over the last couple of years efforts have been focussed on attracting more FDI. For example, in the late 1980s the MENA countries began a significant shift toward trade and FDI openness and the creation of an environment that is more favourable to FDI and exports (AbuAl-Foul and Soliman, 2008). In Sub-Saharan Africa, structural adjustment programmes were also introduced to attract investment after years of policies that deterred foreign investment due to fears that this would result in a loss of political sovereignty, a negative impact on domestic firms and economic degradation with respect to the natural resource sectors (Dupasquier and Osakwe, 2006).

Tables 1 and 2 report levels of FDI inflows across different periods. In Table 1 it is clear that both SSA and the MENA regions received very little FDI prior to the 1980s. However, the 1980s have seen a significant shift in flows particularly for the MENA region. In Table 2 (Panel A) it is also clear that the countries in SSA have received by far the lowest amount of inward investment in the latter period, followed by the MENA countries. Interestingly, the coefficient of variation for all regions, with the exception of Europe and Central Asia, is very similar suggesting that the dispersion of foreign investment activity is uniform. Panel B in the Table shows some encouraging growth in inward FDI for both regions in the present study although SSA lags behind the MENA region to a considerable extent.

Table 1: FDI Inflows (\$ billions) to SSA and MENA Regions (1970 - 1999)

\begin{tabular}{|c|c|c|c|c|}
\hline \multicolumn{5}{|c|}{ Panel A FDI Inflows (1970 - 1979) } \\
\hline Regions & Mean & Std. Dev. & Minimum & Maximum \\
\hline SSA & 0.821 & 0.203 & 0.574 & 1.200 \\
\hline MENA & 0.335 & 1.476 & -3.025 & 2.658 \\
\hline \multicolumn{5}{|c|}{ Panel B FDI Inflows (1980 - 1999) } \\
\hline Regions & Mean & Std. Dev. & Minimum & Maximum \\
\hline SSA & 2.883 & 2.625 & 0.252 & 9.105 \\
\hline MENA & 4.209 & 3.444 & -3.077 & 11.674 \\
\hline
\end{tabular}


Table 2: FDI Inflows to Developing and Emerging Regions (\$ billions)

\begin{tabular}{|c|c|c|c|c|c|}
\hline & IA & $(2000-20$ & & & \\
\hline Regions & Mean & Std. Dev. & Coef of Var. & Minimum & Maximum \\
\hline SSA & 5.92 & 9.11 & 1.54 & 0.74 & 28.70 \\
\hline $\begin{array}{l}\text { East Asia \& } \\
\text { Pacific }\end{array}$ & 66.30 & 104.00 & 1.57 & 1.39 & 328.00 \\
\hline $\begin{array}{l}\text { Latin America } \\
\text { \& Caribbean }\end{array}$ & 30.60 & 42.90 & 1.40 & 0.61 & 122.0 \\
\hline MENA & 13.00 & 27.10 & 1.40 & -0.02 & 87.50 \\
\hline $\begin{array}{l}\text { Europe \& Central } \\
\text { Asia }\end{array}$ & 190.00 & 286.00 & 2.08 & 4.31 & 852.00 \\
\hline \multicolumn{6}{|c|}{ owth in FDI Inflows for SSA and MEI } \\
\hline Regions & \multicolumn{2}{|c|}{$2000-2002$} & \multicolumn{2}{|c|}{ 2003-2006 } & 2007-2012 \\
\hline SSA & \multicolumn{2}{|c|}{11.040} & \multicolumn{2}{|c|}{15.524} & 31.736 \\
\hline MENA & \multicolumn{2}{|c|}{9.295} & \multicolumn{2}{|c|}{45.759} & 87.886 \\
\hline
\end{tabular}

FDI can play a critical role in providing capital for investment, high quality managerial skills and technology transfer. It also creates employment, competition and productivity, transfer of modern technology, increases exports and enhances opportunities for growth and development, particularly in developing and emerging countries (Asiedu, 2002; Akinlo, 2004; Anyanwu and Yameogo, 2015a). Hence, it is important that Sub-Saharan Africa and the MENA region attract sustained foreign investment that can be used to assist in their development programmes and achieve higher levels of growth. Regrettably, as the data suggest, the regions are still at the lower end of the distribution of FDI inflows, which suggests that the reforms over the last couple of decades to attract FDI are still inadequate and have not attracted sufficient foreign investors.

This paper is largely motivated by Asiedu (2002), who examined the determinants of inward FDI to developing countries and questioned whether Africa is different from other potential investment destinations. However, the present study differs in a number of ways. Firstly, it focuses specifically on the determinants of FDI into the two least recipient regions. Both SSA and the MENA region have embarked upon trade liberalisation and reforms (adjustment programmes) at almost the same time, which makes them a more suitable for this study than the common approach of using a sample of developing countries with a huge disparity in characteristics, levels of trade liberalisation and reforms ${ }^{\mathrm{i}}$. Secondly, it incorporates an investigation of the differences between the regions that arise from structural 
and behavioural factors. In addition, the paper departs from much of the literature by using FDI per capita as the dependent variable as this allows for country size in a way that is not possible in the standard FDI inflows as a percentage of GDP. The use of FDI per capita will also avoid any bias in estimates that might arise due to the dominant importance of some large FDI recipient countries. Finally, comparing FDI flows between these regions contributes to the literature as while there are several shared characteristics some factors differ, which presents a platform for further incentives, reforms and complementarities.

Panel data estimation (fixed effects) was applied to a sample of 20 SSA and 11 MENA countries to determine the factors that influence FDI inflows. Findings suggest that trade openness, infrastructure development, and control of corruption positively influence FDI inflows. Surprisingly, rents from natural resources do not significantly influence FDI while inflation negatively affects FDI. In addition, the null hypothesis that both regions are not behaviourally and structurally different in terms of FDI determinants was rejected. When considered separately, SSA performed poorly compared with the MENA countries with the latter group attracting more FDI inflows.

The paper is organised as follows. Section 2 reviews the theoretical and empirical literature on the determinants of FDI. Section 3 develops the hypotheses to be tested. Section 4 describes the variables and presents the preliminary data analysis. Section 5 specifies the models and reports the results followed by a discussion of the implications. The final section concludes.

\section{$2 \quad$ Determinants of FDI}

\section{a) A brief review of the theoretical literature}

Braunerhjelm and Svensson (1996) note the complex nature of the theoretical foundation of FDI and the literature is now fragmented across different areas of economics and international business. The earliest explanation of FDI inflows was from a neoclassical trade theory perspective. The Heckscher-Ohlin model assumed that since commodities vary in relative factor intensities and countries vary in relative factor abundance, capital will move to those countries where the return to capital is higher and the return to labour is lower (Jones, 1957; Hodd, 1967). Aliber (1970) extended the discussion of why capital moves across borders to include differences in the premium associated with exchange rate risk. Multinational firms in 
countries with stronger currencies have an advantage over local firms in countries with weaker currencies since they can borrow capital with a lower exchange rate risk premium (Harvey, 1990).

The neoclassical approach was criticised because of its inability to clarify the nature of FDI flows and was replaced with the concept of oligopoly by Kindleberger (1969) and Hymer (1976) to provide a better explanation of why firms move across borders (Faeth, 2009). Thus, firms will only operate internationally when they possess certain advantages over local firms and where the market to explore these advantages is imperfect (Denisia, 2010). Buckley and Casson (1976) formulated a theory of multinational enterprise within a broad-based intellectual framework defined as internationalisation. This theory suggests that firms internalise markets by bringing the activities linked by the market under common ownership and control and move abroad if the expected benefits exceed the expected costs. Dunning (1979) combined these two concepts to create the eclectic paradigm, which is a combination of traditional trade economics and internalisation theory, which assumes that the likelihood of a firm investing abroad is based on three main factors: the degree to which a firm owns an asset that its competitors do not; whether the firm can benefit from selling or leasing these assets to other firms; and the level of rents that can be earned by exploiting these assets. In all cases, the locational characteristics of the host country are important, where these include market size/market growth, skilled labour, labour costs, synergistic/knowledge-related assets, availability/quality of infrastructure and natural resources (Dunning, 1998; Sun et al, 2002; Dunning, 1980). It is the locational aspects of the eclectic paradigm that separates this theory of FDI from the earlier market structure approaches based on oligopoly and monopoly (Faeth, 2009).

In addition, national policies have had an impact on the determinants of FDI and these have tended to concentrate on attracting investment from abroad rather than emphasise differences in market structure. Hence, FDI can be regarded as a game between the multinational firm and the host government, complicated by the competition between host countries for inward FDI and various inducements and incentives are frequently offered with the intention of influencing the decision of the firm to invest in a particular location (Faeth, 2009). Exchange rates, tariffs and other trade barriers, taxes and the ease with which capital can be repatriated are some of the ways through which host governments influence FDI activity (Lim, 2002). In terms of negative influences, host governments that neglect to ensure a stable environment 
can deter investment as political risk is a disincentive for firms wishing to undertake FDI (Khrawish and Siam, 2010).

\section{b) Empirical studies of FDI determinants}

There is a vast empirical literature on FDI that includes developed and developing countries with interests on various sectors and for different time periods. However, the papers reviewed here focus solely on developing countries and regions as this is the context of the present study. The topics specific to developing countries tend to concentrate on the impact of corruption, rate of return, trade openness and natural resources with mixed findings on their relationship with FDI. Most emphasis has been on market size, education and economic growth. For example, Tsen (2005) attribute the positive significance of human capital to FDI to the fact that foreign investment does not only seek to reduce costs but also acquire access to technology and innovative capacity. Conversely, Oke et al (2012) find an insignificant relationship between education and FDI because of a lack of training and integration in the pool of human capital in their sample. Akin (2009) argued that their findings that FDI is not related to GDP per capita suggests that the small size of the market in low income countries is not an important determinant in the decision to invest internationally, although again this is sample specific. Sanfilippo (2010) argued that the significant relationship between FDI and gross national income shows that their study supports the market size hypothesis. Srinivasan (2011) claimed that the efforts by governments to increase economic growth and GDP per capita are successfully attracting market seeking FDI. In slight contrast, Anyanwu and Yameogo (2015a) found a U-shaped relationship between GDP per capita and FDI. They argued that for FDI to be positively related to GDP per capita, certain thresholds of GDP per capita should be attained.

With respect to infrastructure variables, there is further controversy. Adefeso and Agboola (2012), and Soremekun and Malgwi (2012) find that the positive and significant relationship between infrastructure development (mobile users) and FDI inflows is due to the fast penetration and adoption of mobile phones in the sample of developing countries they studied. However, Wadhwa and Sudhakara (2011) used internet access as a measure of infrastructure and found a negative relationship to FDI. This was justified by the fact that the developing countries in their sample have started using internet services extensively only in the last few years and hence are yet to have a positive influence on FDI. 
Finally, governance measures have been used extensively in FDI studies, and in particular with developing country samples. Woo and Heo (2009) find a negative relationship between FDI and corruption in a sample of developing Asian countries and suggested this was due to weak economic reforms, monopolistic power and rent-seeking behaviours of government officials, all of which deter investors. Political instability was found to have a significant and negative impact on FDI in a study by Buthe and Milner (2008). This is explained by increases in the uncertainty of the political environment that heightens the risk of policy change and thus discourages FDI. Basemera et al, (2012) argue that the influence of free trade has been responsible for increased levels of FDI in a sample of sub-regional governments. A similar line of argument was also adopted by Anyanwu and Yameogo (2015b) following the positive relationship between FDI and trade openness in their study.

\section{$3 \quad$ Hypothesis Development}

The framework for the hypotheses was developed mainly according to the ownership, location and internalisation (OLI) paradigm although with emphasis on locational factors. Country-level studies can only explore the locational aspect of the OLI paradigm. The literature on the location-specific variables of FDI suggests that infrastructure, human capital, natural resources, market size, inflation, corruption, and trade openness influence the patterns of FDI inflows (Tsen, 2005; Mijiyawa, 2015).

\section{H1. Larger market size/growth is positively associated with FDI inflows}

The size of the market can be measured by GDP growth rate or GDP per capita. It is expected that a positive relationship will exist between market size and FDI inflows especially if FDI is motivated by market-seeking activities (Ranjan and Agrawal, 2011). However, while the growth rate of GDP or growth rate of per capita GDP is often argued to be a poor indicator for market seeking FDI activity in developing countries due to the fact that it is difficult to differentiate in the data the strategic imperative behind FDI, this study nevertheless hypothesises a positive relationship with FDI will be found (Akin, 2009).

H2. FDI is positively related to rents from natural resources

Natural resources have been found to be important in attracting FDI, particularly in African continent (Asiedu, 2006; Nsiah and Wu, 2014). The regions under review in this study are 
rich in natural resources and this is the sector that has historically attracted large amounts of FDI, especially the mineral and oil sectors. This study uses rents from natural resources as a percentage of GDP to capture the availability of these resources.

\section{H3. Infrastructure development stimulates FDI inflows}

Available infrastructure increases productivity and thus the return on investment. Therefore a positive relationship between infrastructure and FDI is expected (Asiedu, 2002; Akin, 2009). However, the quality of infrastructure in these countries is highly variable and a quality adjusted measure would be preferred. Unfortunately, data constraints limit the construction of this variable and in common with the literature, infrastructure availability and or development is used. This is proxied by per capita mobile phone users, as is established in similar studies.

\section{H4. Human capital has a positive impact on FDI inflows}

An educated workforce has been recognised as an important determinant of FDI especially when firms are efficiency seeking. Srinivasan (2011) notes that a higher level of education can impact positively on FDI. The measure of human capital this study uses is the number of technical education students per capita. For some of the countries employed in this study, FDI is also attracted in technically oriented industries and not just in labour intensive countries. The use of technical education students is therefore justified because multinationals often seek to improve their technical efficiency particularly in the face of increased competitive pressures. Furthermore, technical knowledge available in a country can positively impact on FDI flows because innovation creates new demands for raw materials leading to FDI in their extraction and production. Such technical knowledge base can be supported through investments in skills acquisition. For example, large investments in education and training increased the stock of skilled labour in some Asia-Pacific countries and thus, helped increase their share of global FDI (Addison and Heshmati. 2003).

\section{H5. Trade openness has a positive impact on FDI inflows}

Countries with greater levels of trade openness and with more links to the world economy attract foreign capital and welcome overseas investment (Srinivasan, 2011; Owusu-Antwi, 2012). Using the established measure of openness (exports plus imports as a share of GDP), 
the study hypothesises a positive relationship with FDI. Evidence of this has been provided by numerous empirical studies for the regions under review. This is particularly important because both SSA and MENA have embarked on adjustment programmes and trade liberalisation over the past two decades and few barriers to trade remain in these regions.

\section{H6. There is a positive relationship between control of corruption and FDI inflows}

Corruption can create a considerable barrier to investment. Corruption impedes investment directly and indirectly (Habib and Zurawicki; Al-Sadig, 2009). Although, several countries in this study are not known for their high levels of control of corruption (Owusu-Antwi, 2012), this study nevertheless hypothesises there is a positive relationship between control of corruption and FDI as the latter can reduce uncertainty in investment activities.

H7. Foreign investors are less likely to invest in countries with high levels of inflation

One of the indicators of stable macroeconomic environment is price stability. Foreign investors are often deterred by high inflation because it erodes their return on investment, raises uncertainty and shows the inability of host government to implement sound macroeconomic policies that are conducive to business activities (Azam, 2010).

\section{$4 \quad$ Sample and Data}

\section{a) Sample countries}

Table 3 shows the sample of countries used in the analysis. The initial sample included all SSA and MENA countries but due to missing data or because some of the values were outliers that would bias the estimates, a few countries were removed. This also guided the chosen time period for the study. Regarding the outliers, preliminary regression plots of the standardised residuals against the fitted values confirms that Bahrain and Qatar are outliers and thus were excluded from the sample in the subsequent analysis. Bahrain and Qatar are likely to be outliers because of their high GDP per capita and thus they do not fit with the developing country profile of the remainder of the sample. 


\begin{tabular}{ll}
\hline SSA Region & Arabia, Syria, Tunisia and Yemen \\
& Angola, Botswana, Burkina Faso, Burundi, Chad, Ethiopia, Ghana, Guinea, Kenya, \\
& Lesotho, Mali, Mauritania, Mozambique, Niger, Rwanda, Senegal, South Africa, \\
Sudan and Uganda
\end{tabular}

\section{b) Variable description}

Given the widely different sizes of the countries under review it is important that the variables used take account of population size in order that comparisons are valid and useful. In addition, levels of development are not constant and some countries have higher income levels than others. Thus, the majority of variables in the modelling are considered on the basis of percentage of total population or values per capita. Data on FDI inflows, pupils in technical education, and mobile users are expressed in per capita terms. The data were obtained from the World Development Indicators, UNCTAD, and the World Bank Governance Indicators. Data definitions and sources are in Table 4.

\section{Table 4 Variable Definitions}

FDI inflows per capita

$\%$ of Population in vocational or technical education

Resource Rent

\% Population of Mobile Phone Users
Trade Openness

Control of Corruption

Inflation

GDP per Capita
FDI inflows by country divided by the total host country population (\$) (UNCTAD 2015)

$\%$ of population enrolled in technical and vocational education (WDI, 2015)

Total natural resources rent are the sum of oil rents, natural gas rents, coal rents, mineral rents and forest rents as a \% of GDP (WDI, 2015)

\% population using mobile telephones either on a post-paid or prepaid basis, proxies infrastructure (WDI, 2015)

Sum of imports plus exports as \% of GDP, proxies the degree of liberalisation, as in Srinivasan, 2011

Measures the extent to which public power for personal gain is controlled (WGI, 2015). Ranges from 0 (lowest) to 100 (highest) rank.

Annual \% change in the cost of consumer goods and services (WDI, 2015)

GDP per capita is gross domestic product divided by midyear population (WDI, 2015) 


\section{c) Preliminary data analysis}

Table 5 reports the descriptive statistics for the variables used in the estimation. It is clear that the MENA region has a higher level of development at the mean, with many values greater than SSA. In particular, the extent of FDI, human capital, infrastructure development, resource rents, and GDP per capita are greater in the MENA sample. The mean trade openness is similar although the SSA sample has a much higher dispersion. The institutional governance variables, that is, control of corruption in this study is higher in the MENA region although the differences are not great. At the mean, inflation is lower in the MENA region including the variation from the mean. Correlation coefficients are listed in Table 6. The coefficients show no high collinearity between the variables.

\section{Table 5 Descriptive Statistics}

\begin{tabular}{|c|c|c|c|c|c|c|c|c|}
\hline \multicolumn{2}{|l|}{ Sample Countries } & \multicolumn{3}{|c|}{ Total } & \multicolumn{2}{|c|}{ MENA } & \multicolumn{2}{|c|}{ SSA } \\
\hline Variables & Mean & Std. Dev. & Min & Max & Mean & Std. Dev. & Mean & Std. Dev. \\
\hline FDI Inflow per Capita (\$ US) & 79.402 & 170.693 & -331.306 & 1458.000 & 151.736 & 251.108 & 39.618 & 78.575 \\
\hline GDP per Capita & 3350.042 & 7233.623 & 108.015 & 56366.570 & 7275.122 & 10921.180 & 1191.248 & 1624.291 \\
\hline Resource Rent (\% of GDP) & 19.402 & 17.599 & 0.256 & 71.605 & 27.878 & 19.744 & 14.740 & 14.336 \\
\hline Infrastructure Development (\% of Mobile Users) & 37.079 & 41.447 & 0.019 & 193.453 & 57.731 & 50.423 & 25.720 & 30.122 \\
\hline$\%$ of Population in Technical Education & 0.546 & 0.798 & 0.012 & 4.599 & 1.102 & 1.081 & 0.241 & 0.291 \\
\hline Trade Openness & 74.641 & 34.157 & 19.356 & 202.850 & 76.786 & 22.025 & 73.461 & 39.255 \\
\hline Control of Corruption & 37.434 & 21.222 & 0.957 & 85.854 & 41.208 & 19.992 & 35.358 & 21.627 \\
\hline Inflation & 9.375 & 20.108 & -9.798 & 324.997 & 5.835 & 6.405 & 11.322 & 24.380 \\
\hline
\end{tabular}

Table 6 Correlation Matrix

\begin{tabular}{|c|c|c|c|c|c|c|c|c|c|}
\hline & & 1 & 2 & 3 & 4 & 5 & 6 & 7 & 8 \\
\hline 1 & FDI Inflow per Capita (\$ US) & 1.000 & & & & & & & \\
\hline 2 & GDP per Capita & 0.484 & 1.000 & & & & & & \\
\hline 3 & Resource Rent (\% of GDP) & 0.259 & 0.482 & 1.000 & & & & & \\
\hline 4 & Infrastructure Development (\% of Mobile Users) & 0.600 & 0.590 & 0.233 & 1.000 & & & & \\
\hline
\end{tabular}




\begin{tabular}{|c|c|c|c|c|c|c|c|c|c|}
\hline 5 & $\%$ of Population in Technical Education & 0.121 & 0.108 & 0.317 & 0.188 & 1.000 & & & \\
\hline 6 & Trade Openness & 0.234 & 0.119 & 0.103 & 0.156 & -0.028 & 1.000 & & \\
\hline 7 & Control of Corruption & 0.244 & 0.324 & -0.334 & 0.276 & -0.069 & 0.215 & 1.000 & \\
\hline 8 & Inflation & -0.013 & -0.078 & 0.200 & -0.096 & -0.050 & 0.159 & -0.219 & 1.000 \\
\hline
\end{tabular}

\section{Models, estimation and results}

\section{a) Panel specification}

The models use a balanced panel of 20 SSA and 11 MENA countries. The data are annual for the period 2000 - 2012. As already identified above, this was mainly due to data availability for some of the variables. Fixed effects estimation was used as the random effects estimator was rejected based on the Hausman test. Panel models are valuable for a number of reasons. Firstly, panel data allow both the cross-section and the time series aspects of the data to contribute to the parameter estimates. Secondly, panel data suggest that countries are heterogeneous. Time series and cross-section studies not controlling for this heterogeneity run the risk of obtaining biased results. Not accounting for country-specific differences in economic or behavioural assumptions, such as countries operating under different political systems or more or less restrictive regulations, can cause serious mis-specification in the models. Thirdly, it may be important to incorporate dynamic effects and these models provide a means to study the dynamics of adjustment (Greene, 1997).

Given the differences between the regions as highlighted by the descriptive statistics (summarised in Table 5), it is important that the models take into consideration possible heterogeneity across countries in order to reduce the risk of obtaining biased estimates. The fixed effects model data used also allows the intercept to vary for each individual country but still assumes that the slope coefficients are constant across the sample. The estimating equation can be expressed

$$
y_{i t}=\alpha_{i}+\beta X_{i t}+\mu_{\mathrm{i}}+\mathrm{v}_{\mathrm{it}}
$$

where $\mathrm{y}$ is FDI inflows per capita in country $i$ at time $t, \mathrm{X}$ is a matrix of independent variables and $\alpha$ and $\beta$ are coefficients to be estimated. $\mu_{\mathrm{i}}$ and $\mathrm{v}_{\mathrm{it}}$ represent the decomposed disturbance 
term where $\mu_{\text {it }}$ are country specific effects and $v_{\text {it }}$ are random errors distributed (Gujarati, 2004).

Equation (1) was first estimated with and without the SSA dummy. With respect to statistical tests, the Chow Test showed that SSA and the MENA countries are behaviourally and structurally different based on the F test and critical values. Given these statistical differences, the significant variables were interacted ${ }^{\mathrm{ii}}$ with the SSA dummy to establish any differences in marginal effects. These behavioural and structural differences could also have accounted for the differences at the means and variations already presented in the preliminary data analysis above.

In the specification tests, all models are acceptable. A Breusch-Pagan/Cook-Weisberg Test for heteroskedasticity indicated the presence of heteroskedasticity and therefore robust standard errors were used to relax the assumptions that the errors were both independent and identically distributed. The GMM results were not reported in this study as the estimates and instruments were inefficient and inconsistent. The inconsistency and inefficiency were not surprising considering that GMM fits better for panel with large numbers of cross-section (N) and small time-series (T). However, the fixed effects technique used is known to control for possible heterogeneity. Tests also revealed no statistical mis-specification of the model and no omitted variable bias. Thus, the conclusion can be drawn that the results obtained from the fixed effects estimation are consistent and not spurious.

\section{b) Results and discussion}

The results are in Tables 7 and 8. The SSA dummy is negative and significant. This implies that all things being equal, the SSA region on average receives less FDI compared to the MENA region. H1 tested the importance of market size. The GDP per capita is positive and significant. Coefficient of the interaction between SSA dummy and GDP per capita was negative and significant. This shows that marginal effect of GDP per capita on FDI inflows is less in SSA than the MENA region. To further support the result of the interaction, the estimated partial coefficient of GDP per capita in SSA was insignificant compared to the positive and significant effect in MENA. These findings most likely reflect that the higher levels of disposable income in the MENA region attract FDI for market seeking opportunities. H2 tested the impact of rents from natural resources on FDI inflows. Surprisingly, this was 
insignificantly related to FDI. These findings were similar to those of Asiedu and Lien (2011) and can be justified with similar arguments. Huge rents generated from natural resources can lead to the appreciation of local currency and thus can diminish the competitiveness of exports. This results in the crowding out of investments in non-natural resource tradable sectors. Some of the countries in the sample often attract huge FDI inflows into their resource sectors and thus, while the exploration of natural resources initially comes with high capital outlay, continued operations within that sector are usually accompanied by smaller cash flows. Also, countries with a significant share of natural resources in total merchandise exports are more prone to external shocks since they are weak in trade diversification. These shocks create macroeconomic instability and can lead to the decline in FDI. 
Table 7: Fixed Effects Estimations (Robust standard errors)

\begin{tabular}{|c|c|c|c|c|c|c|c|}
\hline FDI Inflow per Capita (\$ US) & $\begin{array}{l}\text { Fixed } \\
\text { Effects }\end{array}$ & $\begin{array}{c}\text { Fixed } \\
\text { Effects }\end{array}$ & $\begin{array}{l}\text { Fixed } \\
\text { Effects }\end{array}$ & $\begin{array}{l}\text { Fixed } \\
\text { Effects }\end{array}$ & $\begin{array}{l}\text { Fixed } \\
\text { Effects }\end{array}$ & $\begin{array}{l}\text { Fixed } \\
\text { Effects }\end{array}$ & $\begin{array}{l}\text { Fixed } \\
\text { Effects }\end{array}$ \\
\hline Independent Variables & Model 1 & Model 2 & Model 3 & Model 4 & Model 5 & Model 6 & Model 7 \\
\hline GDP per Capita & $\begin{array}{l}0.014^{*} \\
(0.007)\end{array}$ & $\begin{array}{l}0.014^{*} \\
(0.007)\end{array}$ & $\begin{array}{l}0.014^{*} \\
(0.007)\end{array}$ & $\begin{array}{l}0.013^{*} \\
(0.008)\end{array}$ & $\begin{array}{l}0.014^{*} \\
(0.008)\end{array}$ & $\begin{array}{l}0.013^{*} \\
(0.008)\end{array}$ & $\begin{array}{l}0.014^{*} \\
(0.007)\end{array}$ \\
\hline Resource Rent (\% of GDP) & $\begin{array}{l}-0.137 \\
(0.965)\end{array}$ & $\begin{array}{l}-0.137 \\
(0.965)\end{array}$ & $\begin{array}{c}0.119 \\
(0.987)\end{array}$ & $\begin{array}{c}0.294 \\
(1.150)\end{array}$ & $\begin{array}{l}-0.554 \\
(0.893)\end{array}$ & $\begin{array}{l}-0.099 \\
(0.968)\end{array}$ & $\begin{array}{c}-0.334 \\
(1.048)\end{array}$ \\
\hline Infrastructure Development (\% of Mobile Users) & $\begin{array}{c}2.199 * * * * \\
(0.687)\end{array}$ & $\begin{array}{c}2.199 * * * \\
(0.687)\end{array}$ & $\begin{array}{c}2.379 * * * \\
(0.687)\end{array}$ & $\begin{array}{c}2.284^{* * * *} \\
(0.715)\end{array}$ & $\begin{array}{c}1.795 * * * \\
(0.661)\end{array}$ & $\begin{array}{c}2.203 * * * \\
(0.681)\end{array}$ & $\begin{array}{c}2.249 * * * \\
(0.686)\end{array}$ \\
\hline$\%$ of Population in Technical Education & $\begin{array}{c}-37.269 \\
(30.798)\end{array}$ & $\begin{array}{c}-37.269 \\
(30.798)\end{array}$ & $\begin{array}{l}-16.384 \\
(29.431)\end{array}$ & $\begin{array}{c}-27.983 \\
(34.563)\end{array}$ & $\begin{array}{c}-44.698 \\
(32.431)\end{array}$ & $\begin{array}{c}-36.631 \\
(30.222)\end{array}$ & $\begin{array}{c}-42.864 \\
(32.913)\end{array}$ \\
\hline Trade Openness & $\begin{array}{c}1.969 * * * \\
(0.479)\end{array}$ & $\begin{array}{c}1.969 * * * \\
(0.479)\end{array}$ & $\begin{array}{c}1.628 * * * \\
(0.497)\end{array}$ & $\begin{array}{c}1.893^{* * * *} \\
(0.489)\end{array}$ & $\begin{array}{c}6.052 * * * \\
(1.302)\end{array}$ & $\begin{array}{c}1.974 * * * \\
(0.475)\end{array}$ & $\begin{array}{c}1.996 * * * \\
(0.480)\end{array}$ \\
\hline Control of Corruption & $\begin{array}{c}66.477^{* *} \\
(33.589)\end{array}$ & $\begin{array}{c}66.477 * * \\
(33.589)\end{array}$ & $\begin{array}{c}68.859 * * \\
(33.564)\end{array}$ & $\begin{array}{c}69.932^{* *} \\
(34.208)\end{array}$ & $\begin{array}{c}42.325 \\
(30.529)\end{array}$ & $\begin{array}{c}58.554 \\
(77.767)\end{array}$ & $\begin{array}{l}62.978^{*} \\
(35.235)\end{array}$ \\
\hline Inflation & $\begin{array}{c}-0.606 * * * \\
(0.229)\end{array}$ & $\begin{array}{c}-0.606 * * * \\
(0.229)\end{array}$ & $\begin{array}{c}-0.446 * * \\
(0.227)\end{array}$ & $\begin{array}{c}-0.553 * * \\
(0.232)\end{array}$ & $\begin{array}{c}-0.517^{* *} \\
(0.236)\end{array}$ & $\begin{array}{c}-0.610^{* * *} \\
(0.229)\end{array}$ & $\begin{array}{c}-0.899 * * * \\
(0.325)\end{array}$ \\
\hline SSA Dummy & & $\begin{array}{c}-199.706^{* * *} \\
(67.821)\end{array}$ & & & & & \\
\hline GDP per Capita * SSA & & & $\begin{array}{c}-0.031^{* *} \\
(0.014)\end{array}$ & & & & \\
\hline Infrastructure Development (\% of Mobile Users) * SSA & & & & $\begin{array}{c}-0.513 \\
(0.579)\end{array}$ & & & \\
\hline Trade Openness * SSA & & & & & $\begin{array}{c}-4.944 * * * \\
(1.342)\end{array}$ & & \\
\hline Control of Corruption * SSA & & & & & & $\begin{array}{c}12.212 \\
(74.842)\end{array}$ & \\
\hline Inflation * SSA & & & & & & & $\begin{array}{c}0.368 \\
(0.384)\end{array}$ \\
\hline Cons & $\begin{array}{l}47.14627 \\
29.12621\end{array}$ & $\begin{array}{c}-53.569 \\
(64.803)\end{array}$ & $\begin{array}{c}-91.259 \\
(67.713)\end{array}$ & $\begin{array}{c}-82.554 \\
(77.546)\end{array}$ & $\begin{array}{c}292.237 * * * \\
(99.915)\end{array}$ & $\begin{array}{c}-60.238 \\
(71.414)\end{array}$ & $\begin{array}{c}-16.061 \\
(79.383)\end{array}$ \\
\hline No. of Obs. & 403 & 403 & 403 & 403 & 403 & 403 & 403 \\
\hline F Stat & 13.25 & 7.77 & 7.71 & 7.62 & 8.52 & 7.61 & 7.64 \\
\hline Prob. > F & 0.0000 & 0.0000 & 0.0000 & 0.0000 & 0.0000 & 0.0000 & 0.0000 \\
\hline R-Squared & 0.4097 & 0.6650 & 0.6713 & 0.6664 & 0.6865 & 0.6651 & 0.6655 \\
\hline
\end{tabular}

Robust Standard Errors are in Parentheses; *Significance at the $10 \%$ Level; **Significance at the 5\% Level; ***Significance at the 1\% Level 
Table 8: Marginal Effects of the Significant Variables

\begin{tabular}{|c|c|c|}
\hline Variables & MENA & SSA \\
\hline GDP per Capita & $\begin{array}{l}0.014^{*} \\
(0.007)\end{array}$ & $\begin{array}{l}-0.017 \\
(0.015)\end{array}$ \\
\hline Infrastructure Development (\% of Mobile Users) & $\begin{array}{c}2.284 * * * \\
(0.715)\end{array}$ & $\begin{array}{c}1.771 * * \\
(0.713)\end{array}$ \\
\hline Trade Openness & $\begin{array}{c}6.052 * * * \\
(1.302)\end{array}$ & $\begin{array}{c}1.108^{* * *} \\
(0.401)\end{array}$ \\
\hline Control of Corruption & $\begin{array}{c}58.554 \\
(77.767)\end{array}$ & $\begin{array}{c}70.765 * * * \\
(21.009)\end{array}$ \\
\hline Inflation & $\begin{array}{c}-0.899 * * * \\
(0.325)\end{array}$ & $\begin{array}{c}-0.530^{* *} \\
(0.257)\end{array}$ \\
\hline
\end{tabular}

Infrastructure development is clearly important as a determinant of FDI inflows and it is positive and significant although SSA has a lower elasticity overall than the MENA region. The interaction between infrastructure development and the SSA dummy was negative and the estimated partial coefficient was higher for MENA countries compared to SSA countries. The findings are expected and support the literature on FDI, particularly on the relationship between infrastructure and investment from developed to developing countries. The impact of human capital as a predictor of FDI was tested in H4. The results showed that technical education has an insignificant effect on FDI. The results suggest that human capital in these regions has not yet reached the required threshold in technical education to stimulate efficiency and attract skill-seeking FDI. A test of H5 showed that trade openness is positive and significant although SSA has a lower elasticity. That is, the result of the interaction between the SSA dummy and trade openness was negative and significant. These findings nevertheless, demonstrate the importance of trade openness in attracting FDI.

Results also showed that control of corruption has a positive influence on FDI inflows, however the marginal effect of corruption control on FDI is significantly higher in SSA countries compared to MENA countries. The result of the interaction between control of corruption and the SSA dummy is positive and the partial coefficient is positive but insignificant for the MENA countries. These findings support the empirical evidence that controlling for corruption can be a means through which FDI can be positively influenced. Foreign investors perceive SSA countries to be very corrupt and thus, genuine efforts against corruption will have the most impact on investment in SSA. The impact of Inflation was negative and significant. The partial coefficient shows that the negative impact of inflation will be higher in the MENA region compared to the SSA region. Inflation creates macroeconomic instability, reduces buying power, and erodes the return on investment. 


\section{Conclusion and Policy Implications}

This study investigates the determinants of FDI inflows into two of the least recipient regions, SSA and MENA. The findings reveal that infrastructure development, trade openness and control of corruption encourage FDI into these regions. On the other hand, inflation deters FDI while rents from natural resources do not significantly attract FDI. Some of these findings are not consistent with the stated hypotheses. The analyses also considered whether the regions are behaviourally and structurally different and if so, how they compare in their FDI determinants. The results confirmed differences between the two regions and that the marginal benefits from increases in the quality of FDI determinants will be less for SSA countries compared to the MENA countries.

A number of policy implications follow from these findings. First, trade openness and control of corruption are very important determinants of FDI and thus, efforts targeted at reducing corruption and improving trade policies should be seriously pursued. Second, since rent from resources does not significantly influence FDI, the SSA and MENA regions should encourage more trade diversification by pursuing policies that will increase the competitiveness of the non-resource tradable sectors. Third, serious attention should be paid to technical education because countries with high levels of low-skilled labour are less likely to be attractive to foreign investors focussing on high value-added industries or FDI inflows motivated by efficiency seeking. This is also important because of the spillovers that flow to host country firms from FDI in high skilled sectors that contribute more value added than those from low-skilled sectors. Finally, all things being equal, SSA countries will attract less FDI compared to MENA countries and thus it is crucial that countries and sub-regional blocs in SSA direct their efforts towards programmes that improve their image as international partners. Therefore they should introduce credible policies targeted at restoring confidence and maintaining global relationships, thus countering the negative perception of SSA as a region. 


\section{References}

AbuAl-Foul, B. M. and Soliman, M. (2008), 'Foreign Direct Investment and LDC Exports: Evidence MENA Region', Emerging Markets Finance \& Trade, Vol. 44, No. 2, 4-14

Addison, T. and Heshmati, A. (2003), 'The New Global Determinants of FDI Flows to Developing Countries: The Importance of ICT and Democratisation (No. 2003/45)', WIDER Discussion Papers//World Institute for Development Economics (UNU-WIDER)

Adefeso, H. A. and Agboola, A. A. (2012), 'Determinants of Foreign Direct Investment Inflows in Nigeria: An Empirical Investigation', International Business Management, Vol. 6, No. 1, 83-89

Akin, M. S. (2009), 'How Is the Market Size Relevant as a Determinant of FDI in Developing Countries? A Research on Population and the Cohort Size', In: International Symposium on Sustainable Development, June 9 - 10, 2009. Sarajevo, Bosnia and Herzegovina

Akinlo, A. E. (2004), 'Foreign Direct Investment and Growth in Nigeria: An Empirical Investigation', Journal of Policy Modeling, Vol. 26, No. 5, 627-639

Aliber, R. Z. (1970), 'A Theory of Direct Foreign Investment', The International Corporation, 4, 17-37

Al-Sadig, A. (2009), 'The Effects of Corruption on FDI Inflows', Cato Journal, Vol. 29, No. 2, 267-294

Anyanwu, J. C. and Yameogo, N. D. (2015a), 'What Drives Foreign Direct into West Africa? An Empirical Investigation', African Development Review, Vol. 27, No. 3, 199-215

Anyanwu, J. C. and Yameogo, N. D. (2015b), 'Regional Comparison of Foreign Direct Investment to Africa: Empirical Analysis’, African Development Review, Vol. 27, No. 4, 345363

Asiedu, E. (2002), 'On the Determinants of Foreign Direct Investment to Developing Countries: Is Africa Different?’, World Development, Vol. 30, No. 1, 107-119

Asiedu, E. (2006), 'Foreign Direct Investment in Africa: The Role of Natural Resources, Market Size, Government Policy, Institutions and Political Instability’, The World Economy, Vol. 29, No. 1, 63-77

Asiedu, E. and Lien, D. (2011), 'Democracy, Foreign Direct Investment and Natural Resources', Journal of International Economics, Vol. 84, No. 1, 99-111 
Azam, M. (2010), 'Economic Determinants of Foreign Direct Investment in Armenia, Kyrgyz Republic and Turkmenistan: Theory and Evidence', Eurasian Journal of Business and Economics, Vol. 3, No. 6, 27-40

Basemera, S. Mutenyo, J. Hisali, E. and Bbaale, E. (2012), 'Foreign Direct Investment Inflows to East Africa: Do Institutions Matter?', Journal of Business and Management and Applied Economics, Vol. 1, No. 5, 49-71

Braunerhjelm, P. and Svensson, R. (1996), 'Host Country Characteristics and Agglomeration in Foreign Direct Investment', Applied Economics, Vol. 28, No. 7, 833-840

Buckley P. J. and Casson M. (1976), 'The Future of the Multinational Enterprise', London: The Macmillan Press.

Buthe, T. and Milner, H. V. (2008), 'The Politics of Foreign Direct Investment into Developing Countries: Increasing FDI through International Trade Agreements?', American Journal of Political Science, Vol. 52, No. 4, 741-762

Campbell, B., and Loxley, J. eds., (1989), 'Structural Adjustment in Africa', Springer

Denisia, V. (2010), 'Foreign Direct Investment Theories: An Overview of the Main FDI Theories', European Journal of Interdisciplinary Studies, Vol. 2, No. 2, 104-110

Dielman, T. E. (2005), 'Applied Regression Analysis: A Second Course in Business and Economic Statistics', CA: Brooks/Cole Thomson Learning

Dunning H. J. (1998), 'Location and the Multinational Enterprise: A Neglected Factor?', Journal of International Business Studies, Vol. 29, No. 1, 45-66

Dunning, J. H. (1979), 'Explaining Changing Patterns of International Production: In Defence of the Eclectic Theory', Oxford Bulletin of Economics and Statistics, Vol. 41, No. 4, 269-295 Dunning, J. H. (1980), 'Toward an Eclectic Theory of International Production: Some Empirical Tests’, Journal of International Business Studies, Vol. 11, No. 1, 9-31

Dupasquier, C. and Osakwe, P. (2006), 'Foreign Direct Investment in Africa: Performance, Challenges and Responsibilities’, Journal of Asian Economics, Vol. 17, No. 2, 241-260

Faeth, I. (2009), 'Determinants of Foreign Direct Investment - A Tale of Nine Theoretical Models', Journal of Economic Surveys, Vol. 23, No. 1, 165-196

Greene, W. H. (1997), ‘Econometric Analysis’, Prentice-Hal International, London

Gujarati, D. N. (2004), ‘Basic Econometrics’, Fourth Edition, McGraw-Hill

Habib, M. and Zurawicki, L. (2002), 'Corruption and Foreign Direct Investment', Journal of International Business Studies, Vol. 33, No. 2, 291-307

Harvey, J. T. (1990), 'The Determinants of Direct Foreign Investment', Journal of Post Keynesian Economics, Vol. 12, No. 2, 260-272 
Hodd M. (1967), 'An Empirical Investigation of the Heckscher-Ohlin Theory', Economica, Vol. 34, No. 133, 20-29

Hymer S. H. (1976), 'The International Operations of National Firms: A Study of Direct Investment', Cambridge, MA: MIT Press

Jones, R. W. (1957), 'Factor Proportions and the Heckscher-Ohlin Theorem', The Review of Economics Studies, Vol. 24, No. 1, 1-10

Kandiero, T. and Chitiga, M. (2006), 'Trade Openness and Foreign Direct Investment in Africa', South Africa Journal of Economic and Management Sciences, Vol. 9, No. 3, 355-370 Khrawish, H. and Siam, W. Z. (2010), 'Determinants of Direct Foreign Investment: Evidence from Jordan’, Business and Economic Horizons, Vol. 1, No. 1, 67-75

Kindleberger, C. P. (1969), 'American Business Abroad: Six Lectures on Direct Investment', New Haven and London: Yale University Press.

Lim S. H. (2002). 'How Investment Promotion Affects Attracting Foreign Direct Investment: Analytical Argument and Empirical Analyses', International Business Review, Vol. 17, No. 1, 39-53

Mijiyawa, A. G. (2015), 'What drives Foreign Direct Investment in Africa? An Empirical Investigation with Panel Data', African Development Review, Vol. 27, No. 4, 392-402

Nsiah, C. and Wu, C. (2014), 'The Role of Spatial Dynamics in the Determination of Foreign Direct Investment Inflows to Africa’, African Development Review, Vol. 26, No. 3, 494-507

Nsouli, M. S. M. and Zulu, J. B. (1985), 'Adjustment Programs in Africa: The Recent Experience' (No. 34). International Monetary Fund

Oke, B. O. Ezike, J. E. and Ojogbo, S. O. (2012), 'Locational Determinants of Foreign Direct Investment in Nigeria’, International Business Research, Vol. 5, No. 4, 103-111

Owusu-Antwi, G. (2012), 'Determinants of Foreign Direct Investment: Is It A Better Prescription for Economic Growth in Africa?', International Business and Economic Research Journal, Vol. 11, No. 7, 757-770

Ranjan, V. and Agrawal, G. (2011), 'FDI Inflow Determinants in BRIC Countries: A Panel Data Analysis’, International Business Research’, Vol. 4, No. 4, 255-263

Sanfilippo, M. (2010), 'Chinese FDI to Africa: What is the Nexus with Foreign Economic Cooperation?', African Development Review, Vol. 22, No. 1, 599-614

Soremekun, O. and Malgwi, C. (2012), 'Exploring the Relationship Between Foreign Direct Investment and Mobile Technology in Africa: An Application of Directed Acyclic Graphs', Case Studies in Business, Industry and Government Statistics, Vol. 5, No. 1, 58-66 
Srinivasan, P. (2011), 'Determinants of Foreign Direct Investment in SAARC Nations: An Econometric Investigation', The IUP Journal of Managerial Economics, Vol. 9, No. 3, 26-42 Sun, Q. Tong, W. and Yu, Q. (2002), 'Determinants of Foreign Direct Investment Across China', Journal of International Money and Finance, Vol. 21, No. 1, 79-113

Tsen, W. H. (2005), 'The Determinants of Foreign Direct Investment in the Manufacturing Industry of Malaysia’, Journal of Economic Cooperation, Vol. 26, No. 2, 91-110

UNCTAD, (2015), World Investment Report 2015, (C) United Nations

Wadhwa, K. and Sudhakara, R. S. (2011), 'Foreign Direct Investment into Developing Asia Countries: The Role of Market Seeking, Resource Seeking and Efficiency Seeking Factors', International Journal of Business and Management, Vol. 6, No. 11, 219-226

WDI, (2015), ‘World Bank Development Indicators’, (c) World Bank, Washington DC WGI, (2015), ‘World Bank Governance Indicators’, (C) World Bank, Washington DC Woo, J. and Heo U. (2009), 'Corruption and Foreign Direct Investment Attractiveness in Asia’, Asian Politics and Policy, Vol. 1, No. 2, 223-238

Zheng, P. (2009), 'A Comparison of FDI Determinants in China and India', Thunderbird International Business Review, Vol. 51, No. 3, 263-279

\footnotetext{
${ }^{\mathrm{i}}$ For further details that African countries embarked on adjustment programmes in the 1980s see, Nsouli and Zulu, 1985; Campbell and Loxley, 1989.

${ }^{\text {ii }}$ An interaction is formed as of a product off two (or more) variables. An important application of the interaction variables is that it allows for differences in the slopes of two regression lines. For further reading, see (Dielman, 2005).
} 